\title{
MULTIMODAL SOLUTIONS AS FACTORS OF INCREASING TRANSPORT ACCESSIBILITY - THE CASE OF SLOVAKIA-POLISH BALTIC COAST ROUTE
}

\author{
Michał Małysz* \\ * University of Wrocław, Institute of Geography and Regional Development, \\ Department of Human Geography, Uniwersytecki Square 1, 50-137 Wrocław, Poland \\ michal.j.malysz@uwr.edu.pl
}

\begin{abstract}
Multimodal solutions as factors of increasing transport accessibility - the case of Slovakia-Polish Baltic coast route

Multimodal passenger transport is an essential component of long-distance travel by public transport. It is not possible to establish direct rail or bus connections between all regions of a given country and it is even more difficult to ensure the communication between regions of various countries. However, in order to ensure relatively efficient accessibility and at the same time to maintain profitable connections, possibilities of convenient changes of ways of transport are possible at multimodal interchange nodes, which is the most important element of the infrastructure of multimodal passenger transport. Examples of potential applications of this type of mobility include tourist trips from Slovakia to Baltic Sea resorts in Poland. Over a dozen Polish seaside resorts located on the Baltic coast can become travel destinations for Slovak tourists. The article discusses the capabilities of public transport between Slovakia and the Polish Baltic coast. It also analyses its real-life effectiveness and identifies problems requiring support and implementation of an integrated multimodal passenger transport. This discussion is based on the analysis of timetables, including the basic timetable assumptions. The results of the analysis will include maps showing the differentiation of accessibility of the Polish Baltic coast and an exemplary model improving the performance of public transport between Slovakia and the destinations located on the Polish coast.
\end{abstract}

Key words: public transport, passenger multimodal transport, rail transport, , Baltic Sea, Slovakia resorts

\section{INTRODUCTION}

The performance of public transport depends on many factors, including physical distance, travel time, travel cost and infrastructure. A significant part of those determinants are objective soft factors related to individual preferences. However, public transport is unable to provide direct connections between all subregions, which is caused by, inter alia, considerable diversity of demand. Modelling multimodal passenger transport has been already discussed in the 20th century by Friedrich (1999) in a scientific article about software called VISUM, a public transport planning tool and later by researchers of transport systems and multimodal journeys, including Van Nes (2002), whose work focused on transport networks and their hierarchy and Litman (2008), who presented a multidimensional approach to this issue considering the many ways of transport (transport modes) used in this type of mobility. Recently, this subject has been taken up by Rosik and Kowalczyk (2015), who described prospects for the development of public transport as a result of infrastructure investments, Yatskiv et al. (2017) presented a case study on the 
operation of multimodal passenger transport on the example of Riga. Mrníková et al. (2017) emphasized the importance of integrating various transport modes and Kowalczyk (2019) and who highlighted the role of railways in commuting to large urban centres, pointing out that the train ought to play a key role in long-distance journeys, with the regional and local range of operation of bus transport. Scientific approaches to multimodal passenger transport are therefore varied. More and more multimodal interchange nodes have been and are being built. However, the Covid19 pandemic in 2020 affected many areas of life, including public transport. On many levels, the number of people using buses, trains and trams has significantly decreased and social confidence in mobility using public transport clearly decreased. According to German studies by Buda et al. (2020), in a group of 55,000 people infected with the coronavirus, only 90 became infected while using public transport, which is less than $1 \%$. Nevertheless, the number of passengers of, for example, trains and buses is significantly lower than before the Covid-19 pandemic. Nevertheless, two possible paths of development should be considered. The first one is establishing the right solution that will limit the pandemic and increase confidence in the safety of public transport. The second scenario says that people will gradually be accustomed to the conditions and will use public transport in accordance with the sanitary regime. In both cases, it is advisable that public transport should be unconditionally developed all the time. Therefore, it is necessary to ensure convenient interchange options at nodes in order to improve the communication between different transport modes. So far multimodal passenger transport has already been playing an important role and should be a relevant research topic in the geography of regional, national and international transport.

\section{PURPOSE AND METHODS OF RESEARCH}

The aim of this study is to determine the transport accessibility of the Polish Baltic coast for passengers travelling from Slovakia, to determine the efficiency of multimodal passenger transport and propose solutions to any identified problems in this field. Slovakia, a Central European country is not directly located by a sea. The shortest distance in a straight line to a seashore is between Bratislava, the Gulf of Venice and the region of Trieste, Italy. It is approximately $370 \mathrm{~km}$ and the most convenient access is possible via Austrian and Italian transport systems. In the case of the Baltic Sea, the distance is much longer, but comparable for regions in northern Slovakia, for example the city of Žilina. However, the distance in a straight line between Bratislava and the islands of Wolin and Usedom is about $670 \mathrm{~km}$. On the other hand, the shortest physical distance between any point in Slovakia and the Baltic Sea is about $520 \mathrm{~km}$, which is comparable to the one between Žilina and Gdańsk. Therefore, in practice, the Adriatic Sea is thought to be a more interesting travel destination for Slovaks, not only because of the shorter physical distance between Bratislava and the Adriatic coast, but also due to the more stable weather conditions. Nevertheless, it does not mean that passenger flows to the Baltic Sea resorts cannot be observed. In terms of rail transport and road infrastructure, it may appear at first sight that the journey from Slovakia to the Baltic Sea by public transport should take about $8-9$ hours, preferably from an early morning departure until arrival in the early afternoon. This study will present examples of existing connections between Slovakia and Baltic Sea resorts in Poland, as well as identify possible difficulties and propose solutions that could ultimately improve the accessibility of the Baltic Sea from Slovakia. In the article, a resort is defined as a tourist 
destination or spa village or town. According to the definition proposed by Rancew -Sikora (2007), a resort is a holiday destination visited by people for leisure and recreation purposes. There are over 70 destinations on the Polish coast that can be classified as resorts, but only a dozen of them will be analysed in this article.

The research methods used in this paper include: literature research focusing on Slovak-Polish border area and transport infrastructure, analysis of regional, national and international train and bus timetables, the use of mathematical methods to present the diversity of connections and cartographic presentation methods to illustrate the level of transport accessibility. Multiple tables and maps present the results of research showing the spatial differentiation and possible measures to describe the level of transport accessibility.

The author presents an original formula in order to assess the performance of public transport on defined routes by taking the factors of: physical distance, real distance, length of journey, time of departure and arrival and number of change of transport modes. As a result, a ranking of existing connections between Slovak towns and cities and Polish sea resorts and nodes is presented and discussed. Subsequently the model of multimodal passenger transport is shown as an example of an improved timetable which also includes recommendations for future editions of the timetables with a reduction in the number of changes of transport modes and an increase of transport accessibility to the Baltic Sea coast from the perspective of Slovakia.

\section{REVIEW OF THE RESEARCH OF SLOVAK-POLISH TRANSPORT CONNECTIONS}

Spatial relationships between Slovakia and Poland have been analysed by several geography researchers. One of the earliest papers by Więckowski (2002) focuses on the cooperation between Slovakia and Poland in the public transport planning. The biggest importance in cross-border connections had routes between Prešov and Nowy Sącz via Muszyna. The author notices that there existed over 20 rail connections per day on this route. A similar number of trains were run on the route Žilina - Zwardoń and a dozen of train connections were launched on the route Humenné - Zagórz. As a supplement to the offer, bus connections served the routes: Prešov Nowy Targ, and Zilina - Cieszyn via Czechia. The main route, where buses had a major role in public transport, was Banská Bystrica/Žilina - Nowy Targ, being the shortest connection between Central Slovakia and Kraków. In general, despite quite poorly developed road infrastructure in Poland, the possibilities of traveling by public transport through the Slovak-Polish border were broad.

Michniak (2011) discusses how membership in the EU affected the development of cross-border transport infrastructure in Slovakia and Poland. European funds made it possible to modernize the road infrastructure in the area of former border crossings near Trstená and Chochołów as well as Oravská Polhora and Korbielów. The author also mentions the projects that improved road infrastructure in the Slovak-Polish border area. Nevertheless, not all of the projects were successful, as financial issues caused difficulties in their implementation.

A detailed study on the subject of Slovak-Polish public transport connections is included in the work by Więckowski et al. (2012). Some of the research approaches referred to the transport accessibility of this region and tourism and issues rela-ted to the discussed in this work. The authors mention cross-border railways 
connecting Čadca with Zwardoń, Košice with Muszyna and Medzilaborce with Łupków and notice that the number of rail connections was clearly limited. Despite the presence of three railways, only one day train was run on the route Čadca Zwardoń. It should be emphasized here that the situation was similar in 2020, when there was only one direct rail connection between northern Slovakia and Poland provided by TLK 'Rozewie' train from Žilina to Gdynia. In the work, authors also mention cross-border bus connections serving the subregion around the Tatra Mountains in a very restricted area between Slovak towns like Liptovský Mikuláš, Poprad, Vysoké Tatry and Polish cities like Zakopane and Kraków. The research focuses on the time accessibility between Polish and Slovak cities and towns located on both sides of the Tatra Mountains and on a macroscale between, for example, the capital cities. In 2010 the journey by car between Bratislava and the SlovakPolish border took around 3 hours. However, the next 6 hours had to be spent on the journey to Warsaw, but the forecast for 2030 shows that this time should be shortened by 3 hours, which also means that the estimated length of the journey between Slovakia and Gdańsk will be approximately 8 hours.

Horňák et al. (2013) focus on the competitiveness of long-distance public transport in Slovakia, comparing journey times by various public transport modes. In the majority of cases train was a faster mode than bus, which means that in long distance traveling, like to the Baltic coast, a train should be used for most of the route, which confirms the assumption made by Kowalczyk (2019). The only route, where buses were faster, was Banská Bystrica-Bratislava. As a result, Banská Bystrica should be connected with other nodes like Bratislava or Žilina by a bus integrated with trains and possibilities of easy change of modes at nodes.

The demand side of public transport in Slovakia is presented by Garbarova and Strezova (2015). Despite the development of the length of roads and motorways (so the supply side), the number of passengers in public road transport regularly decreased in years 1995-2013 from about 730 million to 270 million. On the other hand, railways were not significantly developed, but the curve illustrating the number of passengers traveling by train in the years mentioned above was sinusoidal. This result may again point to the important role of rail public transport and trains as the major modes in multimodal passenger transport.

An analysis of the road infrastructure in Slovakia and Poland is performed also by Masárová and Ivanová (2016). They describe the coefficient of localization that shows the level of proportionality of the distribution of roads in the network and makes a comparison of the infrastructure between 2005 and 2013. Undoubtedly the length of roads of national importance, especially motorways and expressways, increased in both countries and the most important in case of traveling between Slovakia and the Baltic Sea were the openings of the A1 motorway between Łódź and Gdańsk in Poland and clear progress in construction of motorways connecting eastern Slovakia with central parts of the country. In the case of Slovakia the biggest density of motorways and expressways appears in the Bratislava and central regions. Therefore, it is crucial to ensure the connection of other regions with important transport nodes like the capital city and Žilina.

In general works about public transport connecting Slovakia and Poland underline untapped potential, which is restricted by infrastructure performance and capacity. As far as the efficiency of connections between Slovakia and Czechia or Austria is high, the main routes to Poland are narrow and have typical mountain 
characteristics. Numerous scientific studies emphasise that the accessibility on the Slovak-Polish border area is insufficient (Więckowski 2018). More investments in infrastructure, especially expressways and railways, are advisable. Consequently, increasing supply, for example by modernizations and creating new long-distance connections may increase demand and, what is described in this paper, potential passenger flows also to the Baltic Sea coast.

\section{THE TIME-EFFECTIVINESS OF THE EXISTING CONNECTIONS BETWEEN SLOVAKIA AND THE POLISH BALTIC COAST}

The major transport system used for traveling around Europe is the TransEuropean Transport Network (TEN-T). Fig. 1 presents possible transport corridors connecting Slovakia and the Baltic coast along with road and rail transport options via Poland, Czechia and Germany.

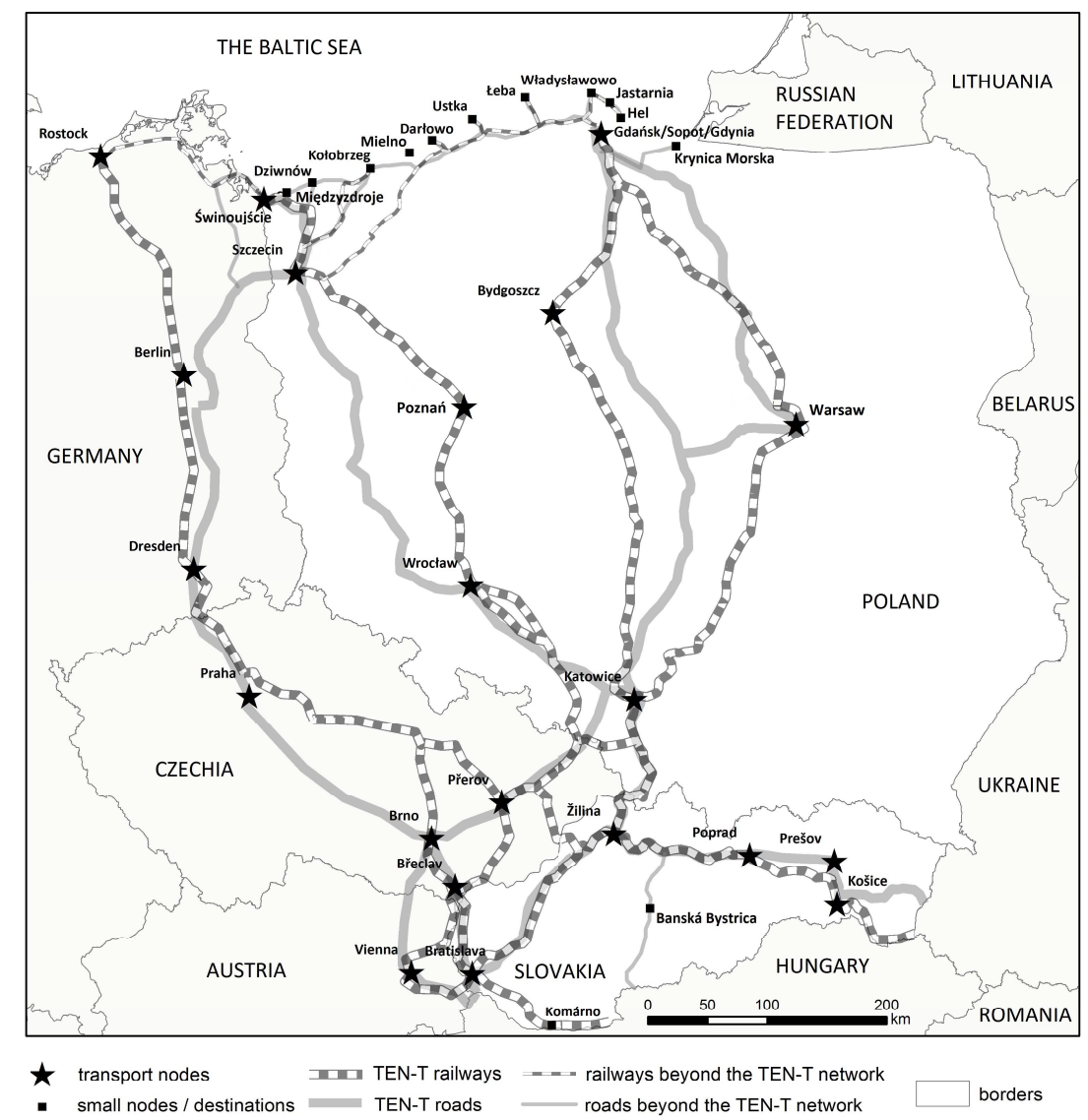

Fig. 1. TEN-T connecting Slovakia and the southern coast of the Baltic Sea

Source: Own study based on https://ec.europa.eu/transport/infrastructure/tentec/tentec-portal/map/ maps.html, doi: 20/09/2020 
A more detailed analysis of the timetables allows data to be obtained showing bus and train connections between Slovakia and the Polish Baltic coast. In multimodal passenger transport, as Kowalczyk (2019) emphasizes, it is advisable that the train should cover the longest possible section of the route to the interchange node. The theory of the main role of rail and bus transport in sustainable tourist mobility is also mentioned by Høyer (2004) as well as in the 'hub and spoke' model, described by Huang et al. (2018), where bus lines serving in a strictly defined area bring passengers to multimodal nodes concentrated around rail transport. Consequently, the train becomes a way of mass transport in long-distance journeys. It is important to ensure the most comfortable change between those transport modes. Such changes should already be possible on bimodal nodes, the concept of which is analyzed in more detail by Bolkovska and Petuhova (2017).

Some cities and towns, which are also important transport nodes, were selected for analysis in this work. Bratislava was chosen as the main starting point for the journey and Košice, Žilina and Banská Bystrica were also taken into account as a reference to various regions of Slovakia. Warsaw, Wrocław and Szczecin were chosen as examples of Polish interchange nodes on the route to the Baltic coast. As regards resorts located on the Polish Baltic coast the following destinations were chosen: Świnoujście, Międzyzdroje, Dziwnów, Kołobrzeg, Mielno, Darłowo, Ustka, Łeba, Władysła-wowo, Jastarnia, Hel, Gdańsk, Sopot, Gdynia and Krynica Morska. Gdańsk and Gdynia are two destinations which also play a very important role in multimodal passenger transport, being also interchange nodes. Some of them located in the direct neighbourhood of national parks, are spa resorts as well as sea ports offering ferry connections to Scandinavian countries. The analysis was based on the last period of 2019/2020 and the first period of the 2020/2021 timetable edition applicable during the time of the lowest possible accessibility to the Baltic resorts during the year without the periodic seasonal connections launched only during the summer holidays (autumn and winter).

Baltranaite et al. (2017) draw attention in their work to the seasonality noticeable in this region, forced by geographical factors, mainly climatic, but underlining the general important role of the Baltic region in tourism shaped by numerous attractions. Therefore, it is advisable to assume the most difficult conditions that are possible, adapt solutions to them and then modify suggestions to periodic and seasonal increases in the level of transport accessibility. A survey conducted by the author clearly emphasized the importance of travel time when choosing the means of transport, the analysis is based on the shortest possible journey from point A to point B marked in the timetable. As a result, the analysis includes a journey requiring 10 hours, but with two changes, not a journey requiring 15 hours, but with one change. However, time is only a fraction of the performance of a given connection. A wider model, including punctuality was described by Eboli and Mazzulla (2012). In the case of this analysis, the number of factors was limited primarily to easily measurable hard factors. The stages of the analysis were divided into three parts. In the first stage of the study, a basic formula was put forward to assess the public transport performance for connections from four Slovak nodes to chosen Baltic resorts and transport nodes in Poland. In the first formula, generally called the 'Possibilities of Public Transport Indicator' (PoPT) three factors were taken into account. The distance travelled was considered as a positive factor, assuming that reaching the furthest possible destination is an expected situation. On the other hand, the number of transport modes used and the number of hours travelled roun- 
ded to half an hour were chosen as negative factors. In order to determine the PoPT indicator, the following formula is calculated:

$$
P o P T=\frac{d_{r}}{n \times h},
$$

where PoPT - Public Transport Performance Indicator, $d_{r}$ - actual distance in accordance with the timetable (in kilometers), $n$ - number of used transport modes and $h$ - travel time (hours).

The indicator describes public transport performance within a range $(0,100]$; value 0 cannot be achieved and 100 means that the real distance equals the physical distance, which is defined by Drzewoszewska et al. (2013) as the distance in a straight line, using one means of transport with an average speed of $100 \mathrm{~km} / \mathrm{h}$. In practice, this means covering the distance of $600 \mathrm{~km}$, for example between Žilina and Hel in a straight line in 6 hours. This is naturally a purely theoretical possibility, and value is unlikely to be equal to the distance in a straight line. The indicator is very sensitive to the number of their changes. If there are more than two chan -ges, so when the value equals 3 , the given connection is no longer attractive and the likelihood that travellers will opt for this connection is very low. A long journey taking up to 20 hours is also discouraging. In general, PoPT with a value above 20 indicates a fairy well-performing connection, while a PoPT of 50 is a sign of a very convenient and highly comfortable connection. On the other hand, a PoPT below 10 is associated with a connection characterized by low attractiveness, a long travel time and also requires several changes of transport modes. The measured values for the above-mentioned transport nodes and resorts are presented in Tab. 1.

Tab. 1. PoPT values for connections from the analysed transport nodes along with mean vales for destinations

\begin{tabular}{ccccc}
\hline & \multicolumn{3}{c}{ Ultimate PoPT } & \\
\hline Destination & Bratislava & Košice & Mean & $\Delta$ \\
\hline Warszawa & 38.21 & 21.56 & 29.88 & 29.88 \\
Wrocław & 36.20 & 18.80 & 27.50 & 27.50 \\
Sopot & 33.33 & 17.60 & 25.47 & 25.47 \\
Gdańsk & 33.24 & 17.39 & 25.31 & 25.31 \\
Gdynia & 32.50 & 17.15 & 25.60 & 25.60 \\
Szczecin & 20.93 & 13.75 & 17.34 & 17.34 \\
Kołobrzeg & 18.13 & 14.12 & 16.13 & 16.13 \\
Władysławowo & 19.05 & 12.09 & 15.57 & 15.57 \\
Świnoujście & 17.87 & 12.50 & 15.18 & 15.18 \\
Międzyzdroje & 17.84 & 12.42 & 15.13 & 15.13 \\
Jastarnia & 17.55 & 11.48 & 14.52 & 14.52 \\
Hel & 17.33 & 11.22 & 14.28 & 14.28 \\
Ustka & 16.73 & 10.24 & 13.49 & 13.49 \\
Mielno & 12.45 & 13.92 & 13.19 & 13.19 \\
Krynica Morska & 16.66 & 9.40 & 13.03 & 13.03 \\
Łeba & 14.51 & 9.86 & 12.18 & 12.18 \\
Dziwnów & 11.98 & 12.30 & 12.14 & 12.14 \\
Darłowo & 12.46 & 8.68 & 10.57 & 10.57 \\
\hline
\end{tabular}

Source: Own study based on the E-podroznik.pl timetable. 
However, the PoPT indicator has some drawbacks that can lead to incorrect conclusions. Note that the indicator does not include the information whether the route is the shortest as possible. The distance is described only by the length of route, but it does not show if it is not unnecessarily extended. It is therefore advisable to improve the PoPT indicator by adding an additional parameter, which is the route optimization indicator (RO). It is a simple quotient of the distance in a straight line to the actual route length according to the timetable and is expressed as:

$$
R O=\frac{d_{s}}{d_{r}},
$$

where $R O$ - route optimization indicator, $d_{s}$ - distance in a straight line (in kilometers) and $d_{r}$ - actual distance in accordance with the timetable (in kilometers).

The product of RO and PoPT indicator allows to define a modified PoPT indicator with added information whether the selected route is indeed the shortest possible and the movement is mostly towards the destination. The product of PoPT and RO equals a PoPT value decreased by a level of difference between the actual travel route with the shortest possible, i.e. a straight line. If the travel distance is very close to the shortest, the RO index takes a value close to 1, so it does not significantly reduce the PoPT index. On the other hand, a greater deviation from the shortest route forces a lower value of the RO index. The values of the PoPT modified by RO (Modified PoPT) for particular routes are presented in Tab. 2.

Tab. 2. Values of the modified PoPT indicator for connections from the analysed transport nodes along with the mean value for destinations

\begin{tabular}{cccccc}
\hline \multicolumn{5}{c}{ Modified PoPT } \\
\hline Destination & Bratislava & Banská Bystrica & Košice & Žilina & Mean \\
\hline Warszawa & 38.21 & 27.20 & 21.56 & 33.45 & 30.11 \\
Gdynia & 32.50 & 30.95 & 17.15 & 28.43 & 27.65 \\
Sopot & 33.33 & 30.58 & 17.60 & 27.61 & 27.28 \\
Gdańsk & 33.24 & 30.05 & 17.39 & 27.26 & 26.98 \\
Władysławowo & 19.05 & 17.94 & 12.09 & 16.67 & 16.44 \\
Wrocław & 23.29 & 13.50 & 13.37 & 10.60 & 15.19 \\
Jastarnia & 17.55 & 13.26 & 11.48 & 15.33 & 14.41 \\
Hel & 17.33 & 13.04 & 11.22 & 14.53 & 14.03 \\
Szczecin & 10.96 & 15.91 & 13.75 & 12.02 & 13.16 \\
Mielno & 11.76 & 11.78 & 13.92 & 11.21 & 12.17 \\
Ustka & 13.22 & 12.69 & 9.25 & 11.95 & 11.78 \\
Międzyzdroje & 8.59 & 15.41 & 10.07 & 11.93 & 11.50 \\
Świnoujście & 8.34 & 14.96 & 10.14 & 11.70 & 11.28 \\
Darłowo & 12.46 & 11.98 & 8.68 & 11.38 & 11.13 \\
Krynica Morska & 13.17 & 11.98 & 7.99 & 11.23 & 11.09 \\
Kołobrzeg & 7.28 & 11.38 & 14.12 & 9.60 & 10.60 \\
Dziwnów & 6.39 & 11.57 & 7.38 & 8.26 & 8.40 \\
Łeba & 6.45 & 8.87 & 4.45 & 4.84 & 5.07 \\
\hline
\end{tabular}

Source: Own study based on the E-podroznik.pl timetable. 
After all a significant problem related to public transport remains unsolved. Departure/arrival times, especially in tourism, often become the decisive factor determining the choice of the transport mode. Ideally the journey should preferably end at the place of the destination at the beginning of the check-in time, so that travellers can rest after the journey. Accordingly, travels definitely should not end during the midnight hours. In practice, such situations may occur when a day train is delayed by several hours instead of reaching the place of destination at, for example, 10:00 p.m. Also, starting the journey at noon has no economic benefit at the destination, as the time of arrival is late. The optimal arrival time is around 2 p.m., because hotel rooms are usually already prepared for guests by this time (Małysz 2019). Moreover, taking the night train is relatively comfortable, especially in couchette and sleeping carriages. What is worth emphasizing is the fact that a night train departs from the interchange station before midnight and the timetable does not force the passenger to wait for the train in the middle of the night. In order to evaluate the efficiency of the journey in terms of departure time, a variable relating to the departure/arrival times should be included in the PoPT indicator. Consequently, it will allow the possibility to determine the optimal travel time depending on the length of the route. The weights reflecting the most preferred departure times are included in Tab. 3.

Tab. 3. Point weights describing the connection efficiency in relation to the departure time

\begin{tabular}{ccl}
\hline Time interval & Weight & Comments \\
\hline 01:00-05:00 & 0.50 & Early hours are optimal for earlier arrival \\
05:00-09:00 & 1.00 & Optimal and comfortable hours \\
09:00-12:00 & 0.50 & Less potential due to later start of the journey \\
12:00 - 16:00 & 0.25 & Late arrival and possible in the middle of the night \\
16:00-22:00 & 0.50 & Time of departures of night trains \\
22:00-01:00 & 0.75 & Comfortable time of departures of night trains \\
\hline
\end{tabular}

Source: Own study.

As a result, the modified PoPT indicator is multiplied by the weight provided above, depending on the departure time of the fastest and most comfortable connection in the timetable. Eventually, the Ultimate PoPT indicator depends on the distance, the length of the route in relation to the shortest possible route, the number of transport modes, the time of journey and the departure and arrival times. However, the expected situation that does not require any improvement, for instance when: one transport mode is used, the route is as short as possible, the average travelling speed is $100 \mathrm{~km} / \mathrm{h}$, the journey begins in the morning, and thus the destination is reached early in the afternoon, is only theoretical. Then the Ultimate PoPT is 100, which is, as mentioned above, it is an unattainable value in practice.

The ultimate PoPT (hereinafter referred to as PoPT) values for connections from four Slovak nodes and the mean values for specific destinations are presented in Tab. 4. 
Tab. 4. PoPT indicators for connections from the analysed transport nodes and the mean values for specific destinations

\begin{tabular}{cccccc}
\hline \multicolumn{5}{c}{ Ultimate PoPT } \\
\hline Destination & Bratislava & Banská Bystrica & Košice & Žilina & Mean \\
\hline Warszawa & 38.21 & 27.20 & 21.56 & 33.45 & 30.11 \\
Gdynia & 34.05 & 28.43 & 17.15 & 30.95 & 27.65 \\
Sopot & 33.33 & 27.61 & 17.60 & 30.58 & 27.28 \\
Gdańsk & 33.24 & 27.26 & 17.39 & 30.05 & 26.98 \\
Władysławowo & 19.05 & 16.67 & 12.09 & 17.94 & 16.44 \\
Jastarnia & 17.55 & 15.33 & 11.48 & 13.26 & 14.41 \\
Hel & 17.33 & 14.53 & 11.22 & 13.04 & 14.03 \\
Mielno & 11.76 & 11.21 & 13.92 & 11.78 & 12.17 \\
Wrocław & 17.46 & 10.60 & 13.37 & 6.75 & 12.04 \\
Ustka & 13.22 & 11.95 & 9.25 & 12.69 & 11.78 \\
Darłowo & 12.46 & 11.38 & 8.68 & 11.98 & 11.13 \\
Krynica Morska & 13.17 & 11.23 & 5.99 & 11.98 & 10.59 \\
Szczecin & 8.22 & 6.01 & 13.75 & 7.96 & 8.98 \\
Międzyzdroje & 8.59 & 5.96 & 7.55 & 7.71 & 7.45 \\
Świnoujście & 8.34 & 5.85 & 7.60 & 7.48 & 7.32 \\
Kołobrzeg & 3.64 & 4.80 & 14.12 & 5.69 & 7.06 \\
Dziwnów & 3.20 & 4.13 & 5.54 & 5.78 & 4.66 \\
Łeba & 3.22 & 2.42 & 1.11 & 4.44 & 2.80 \\
\hline
\end{tabular}

Source: Own study based on the E-podroznik.pl timetable.

Generally, the level of accessibility of the Polish Baltic coast from the Slovak perspective can be divided into four classes. The first one consists of interchange stations and resorts with a mean PoPT value of about 30, which means that the destination can be reached in a relatively short time and with an acceptable number changes of modes. The second one in this case, for example Władysławowo, should be merged with the third class, where PoPT values are between 10 and 20 . Usually, in this case the journey includes two or more changes of modes, which is an inconvenience and involves some risk of lack of communication. The lowest class includes destinations with poor accessibility, when the journey requires more than three changes of modes, which is overwhelmingly unacceptable. What has to be noticed is that the resorts in the lowest class are not far from Slovakia according to the physical distance, so the low accessibility must be the result of limitations related to public transport, which requires actions to improve travel conditions on problematic routes like, for example, Bratislava - Świnoujście.

\section{MULTIMODAL TIMETABLE AS A STIMULUS OF PASSENGER FLOWS}

The aim in multimodal passenger transport is to collect passenger flows from many regions and thus to use mass transport, such as trains, to bring them to interchange nodes offering transfer options in many different directions. If a destination 
has access to railway infrastructure, it is advisable to provide access by train, without relying strictly on the multimodal passenger transport options, but preferably a mass method of transport like a train. Fig. 2 presents a theoretical travel time from Bratislava and Košice to the Baltic Sea and the travel options from Slovakia to Świnoujście and Hel, taking into account only rail transport. The isochrone method used on the figure represents the green areas available within 4-5 hours. The red color, on the other hand, indicates the area that requires over 10 hours of traveling by train.

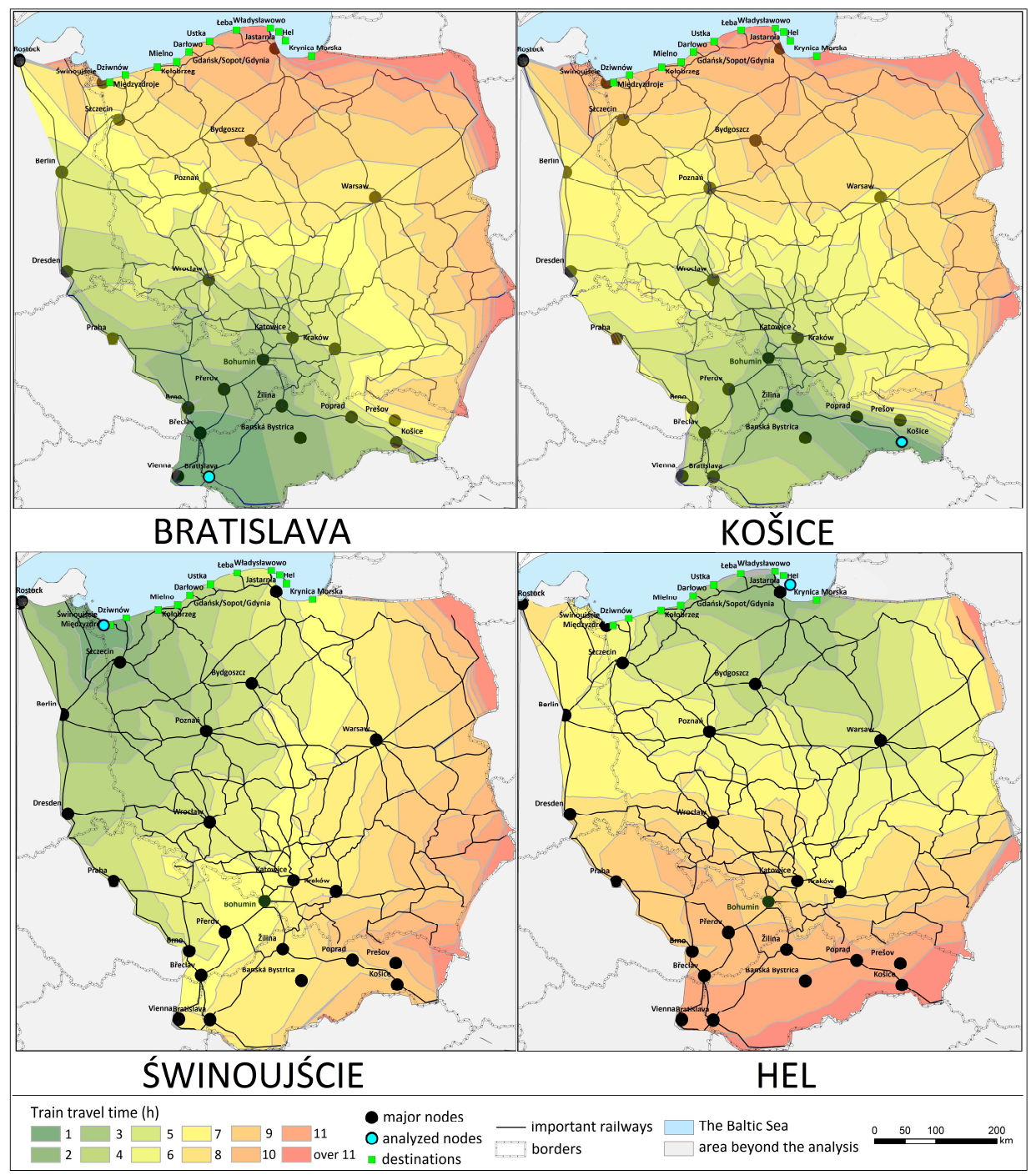

Fig. 2. Theoretical travel time to the Baltic Sea from Bratislava and Košice, and from Slovakia to Swinoujście and Hel by train

Source: Own study based on data from PKP Polskie Linie Kolejowe (www.plk-sa.pl) and Open Railway Map (www.openrailwaymap.org). doi: 16/10/2020. 
It is clear that, in theory, the rail infrastructure allows travel from Slovakia to the Baltic Sea in less time than according to the timetable. The PoPT indicator indicates the relatively good accessibility of Władysławowo, Jastarnia and Hel. In theory, the trip to Hel from Slovakia should take only 10 hours when departing from Žilina. In practice, however, it is 4 hours longer. The differences in connections to Świnoujście are even more significant. In theory it is possible to travel from Bratislava to Świnoujście in 8 hours, but in practice the fastest journey takes 16 hours, which is also reflected in the low value of PoPT for the Bratislava - Swinoujście route. This proves the existing still unused potential of the infrastructure, the lack of appropriate communication at the nodes and inadequate planning of the timetable that unnecessarily extends the travel time.

Based on the analysis of connections in the 2020/2021 timetable and its planned extensions (postponed due to the pandemic), certain time intervals should be determined at specified interchange stations when the largest number of trains depart from it in the largest possible number of directions. In Katowice, this kind of time interval is observed from 05:00 a.m. to 09:00 a.m. when direct trains are scheduled to depart to: Słupsk (very well connected with Ustka), Kołobrzeg, Świnoujście and Gdynia, providing interconnections with the entire Polish coast. However, taking into account the short time needed to travel from Slovakia, it would be necessary to start the journey at 02:00 a.m., which is a disadvantage. Still, if the departure time from Bratislava and Košice is 05:00 a.m., it would be possible to arrive to Katowice at 08:00 a.m. This, on the other hand, would allow the switching of trains only travelling to Gdynia. Another example is traveling to Wrocław via Bohumín with 45 minutes for a change and continuing the journey to Kolobrzeg. However, it would still be difficult to reach Wolin Island, as the train to Świnoujście would not depart until 11:30 a.m. This option would also require spending up to 12 hours in the train from 5:00 a.m. to 5:00 p.m. A departure from Bratislava at 5:00 a.m. would also allow to arrive in Warsaw at 10:00 a.m. However, also in this case, the convenient travel options are very limited according to the 2020/2021 timetable. As a consequence, in order to enable easy travelling from Slovakia to the Baltic Sea, it is clearly advisable to use night trains, which allows spending the night time travelling to the interchange nodes, arrival there in the early morning and continuing the journey by, for example, bus to the final destination. The model of such connections including communication and suggestions for creating new connections is presented in Fig. 3.

The presented model is based on the existing rail connections and slightly modifies the basic timetable, extending communications at the nodes with a possible minimum number of changes of time and the shortest routes of the rail connections. Some of the resorts are not very popular and from an economic point of view there are cases when communication is limited which is justified by the high degree of seasonality of a given resort. In the presented model, the assumption is to launch a direct carriage from Bratislava (via the existing EN Metropol train Budapest - Berlin/Warsaw) and Humenné to the Bohumín station, where it would be possible to travel to Wrocław via Opole and Warsaw via Katowice. It would be possible from Wrocław where departing the Nightjet to Berlin and traveling by a new IC train from Wrocław to Szczecin via Zielona Góra to the Świnoujście station, as well as to IC 'Bosman' train to Kołobrzeg would be possible. In both cases the time between the arrival of Nightjet train and the departure of IC trains to Świnoujście and Kołobrzeg would be around 50 minutes, which would ensure the relatively high 
certainty of a safe change. Other possible connections are illustrated in Fig. 3. In relation to the presented assumptions. Tab. 5 presents the values of the ultimate PoPT indicator after the eventual implementation of the model.

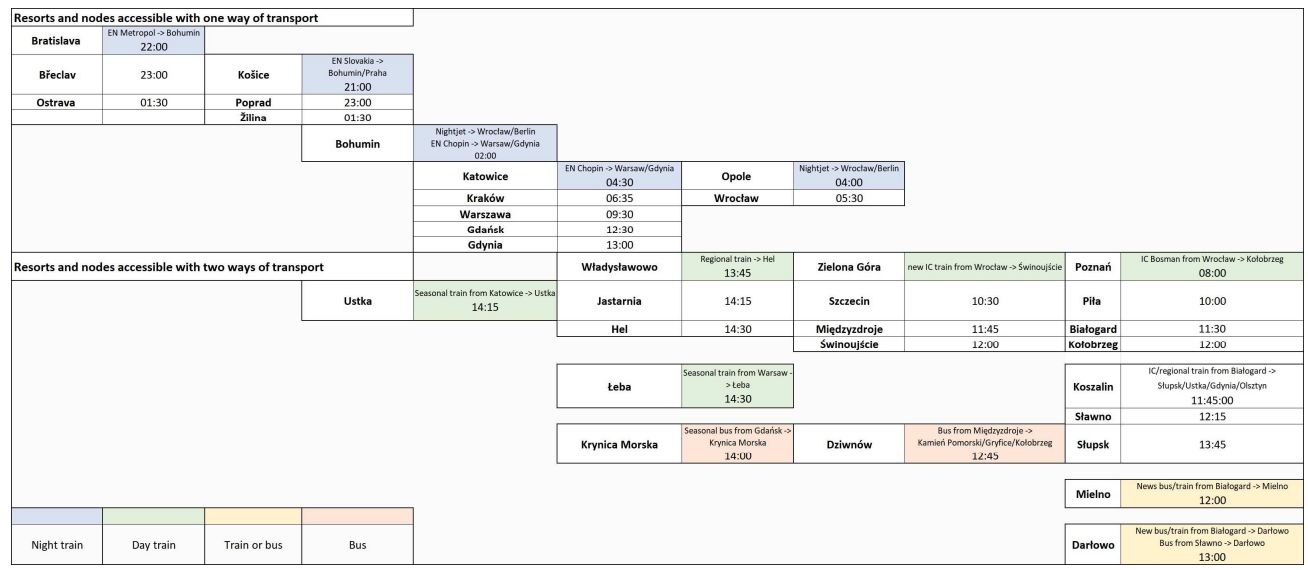

Fig. 3. An exemplary model of multimodal connections from Slovakia to Polish Baltic resorts

Source: Own study based on timetables (www.e-podroznik.pl), doi: 30/10/2020.

Tab. 5. The Ultimate PoPT values for the proposed interconnections in the multimodal connection model

\begin{tabular}{cccc}
\hline \multicolumn{4}{c}{ Ultimate PoPT after implementation of the model } \\
\hline Destination & Bratislava & Košice & Mean \\
\hline Warszawa & 38.21 & 21.56 & 29.88 \\
Wrocław & 36.20 & 18.80 & 27.50 \\
Sopot & 33.33 & 17.60 & 25.47 \\
Gdańsk & 33.24 & 17.39 & 25.31 \\
Gdynia & 32.50 & 17.15 & 25.60 \\
Szczecin & 20.93 & 13.75 & 17.34 \\
Kołobrzeg & 18.13 & 14.12 & 16.13 \\
Władysławowo & 19.05 & 12.09 & 15.57 \\
Świnoujście & 17.87 & 12.50 & 15.18 \\
Międzyzdroje & 17.84 & 12.42 & 15.13 \\
Jastarnia & 17.55 & 11.48 & 14.52 \\
Hel & 17.33 & 11.22 & 14.28 \\
Ustka & 16.73 & 10.24 & 13.49 \\
Mielno & 12.45 & 13.92 & 13.19 \\
Krynica Morska & 16.66 & 9.40 & 13.03 \\
Łeba & 14.51 & 9.86 & 12.18 \\
Dziwnów & 11.98 & 12.30 & 12.14 \\
Darłowo & 12.46 & 8.68 & 10.57 \\
\hline
\end{tabular}

Source: Own study based on the E-podroznik.pl timetable. 
The proposed model of multimodal public transport allows the increase of the accessibility to many Polish Baltic resorts, as well as some interchange stations. The improvement in transport accessibility is clearly noticeable in the case of Łeba, Dziwnów, Świnoujście and Międzyzdroje, as well as Wrocław and Szczecin. In addition, the model provides an alternative night train connection to Gdańsk, Sopot and Gdynia, the resorts of the Hel Spit and Central Pomerania. In all cases, the existing connections provide more convenient travel conditions, which is reflected by the final PoPT indicator. Fig. 4 shows routes between the interchange station and the destination at a regional scale, as presented in the model.

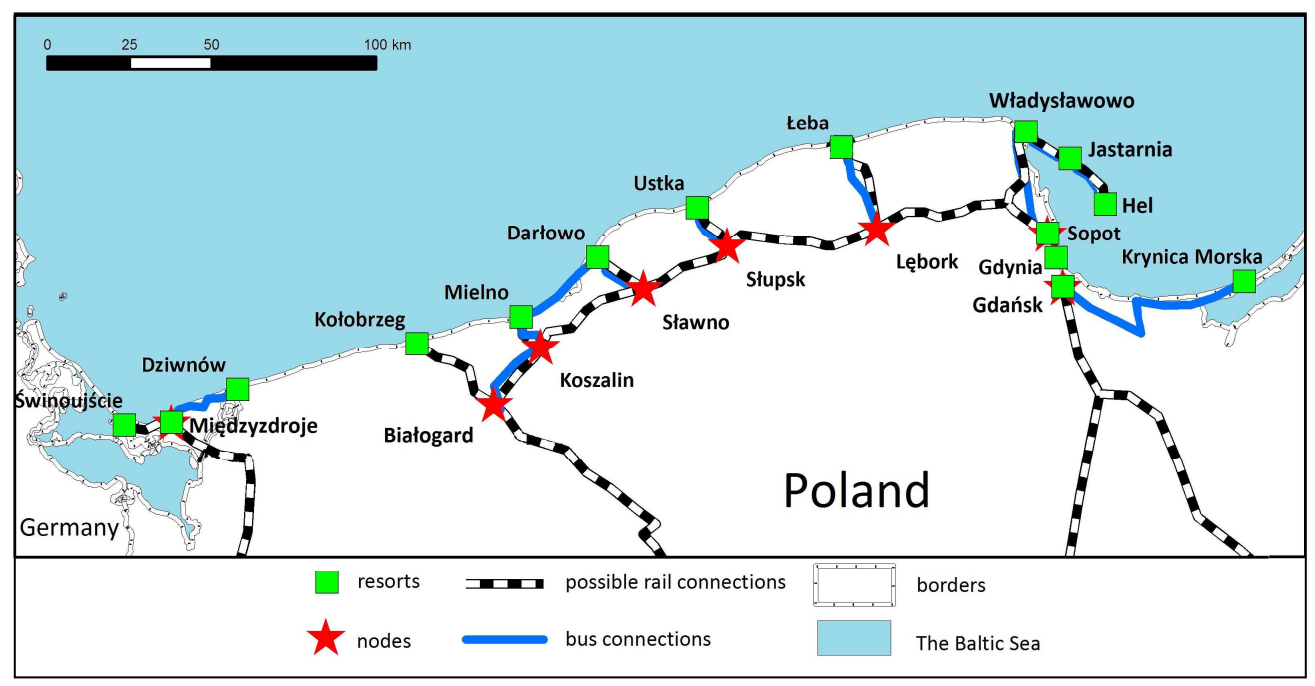

Fig. 4. Multimodal passenger transport options on the Polish Baltic Sea coast Source: Own study.

As a result, adequate communication would be provided in the first stage at major transport nodes such as Wrocław or Warsaw and then at regional nodes in Pomerania, including: Szczecin, Gdańsk, Gdynia and Białogard. A further journey by train to selected resorts and by bus to almost all resorts from those nodes would be possible.

The model also has some disadvantages, including the need to change trains several times. The number of changes would be reduced, if the TLK 'Rozewie' train departing from Žilina to Gdynia was restored. However, it is difficult to predict whether this train is again included in the timetable. The routes of trains EN Metropol and EN Slovakia are east-west routes, which are not preferred in terms of passenger flows to the Baltic Sea. As a result a connection with a north-south route, like Nightjet or EN Chopin (from Wienna to Berlin and Warsaw) must become the point of interest in this case. Moreover, if these trains are delayed, this could generate further delays on the other routes. Perhaps in the future, a new Nightjet train may be launched, for example from Vienna to Gdynia via Wrocław. This is one of the possible development scenarios for night connections in Poland (Małysz 2020). In this case, the residents of Bratislava could also benefit from a very comfortable direct night connection and the reduced number of changes would increase the 
quality of traveling. New passenger flows should be stimulated by the supply of rail connections to interchange nodes and then direct bus connections to resorts. With the development of multimodal passenger transport, it would be advisable, as also proposed by Le-Klähn and Hall (2015), to create a multimodal ticket for rail and bus services. Full integration, also in a form of full passenger information system and travel facilities, is an obligatory element of this well-functioning system. As a result, an increased demand may reveal a symptom of efficient multimodal passenger transport, as well as improved accessibility to the Baltic coast from the perspective of Slovakia.

\section{CONCLUSIONS}

Multimodal public transport is the future of public transport. Direct connections between all regions are rarely possible, therefore it is necessary to facilitate changes on interchange nodes. Slovakia does not have direct access to the sea and may benefit from the development of multimodal transport infrastructure in Poland, which will provide it with much easier traveling to the Baltic Sea coast. The paper shows how timetables influence the modelling of accessibility, which differs significantly from the theoretical physical accessibility measured by distance in a straight line, as illustrated on maps using isochrones. In general, the level of accessibility to the Baltic Sea from Slovakia by public transport can be defined as sufficient only in the case of Gdańsk, Sopot and Gdynia. It is possible to travel from Bratislava to those destinations in about 10 hours, which is acceptable and is described as a quite comfortable journey. However, this transport network still has some possibilities that are not used. The travel time from Žilina can be even shorter, as long-distance trains from Žilina to the Baltic Sea will perhaps be launched again, following the example of the TLK 'Rozewie' train included in the 2019/2020 timetable. Despite the Covid-19 pandemic in 2020, further development of multimodal infrastructure should be planned, which, through its numerous facilities for travellers, will encourage traveling by efficient public transport. The role of public transport through numerous investments supported by the European Union may nevertheless increase, so, as a result, fast trains and modern regional buses may connect Slovakia and the Polish Baltic coast, operating on the basis of cooperation and coopetition. The integrated information and cooperation between rail and bus operations is also the key to well-functioning public transport and improving the transport accessibility of regions in many different cases. Consequently, the established transport options will complement each other, while continuous improvements in transport accessibility will stimulate regional and local development, thus contributing to the greater attractiveness of specific destinations and improvement in the quality of everyday life.

\section{REFERENCES}

BALTRANAITĖ, E., JURKUS, E., POVILANSKAS, R. (2017). Impact of physical geographical factors on sustainable planning of South Baltic seaside resorts. Baltica, 30, 119-131. DOI: 10.5200/baltica.2017.30.13.

BOLKOVSKA, A, PETUHOVA, J. (2017). Simulation-based public transport multi-modal hub analysis and planning. Procedia Computer Science, 104, 530-538. DOI: 10.1016/ j.procs.2017.01.169. 
BUDA, S., AN DER HEIDEN, M., ALTMANN, D., DIERCKE, M., HAMOUDA, S., REXROTH, U. (2020). Infektionsumfeld von erfassten COVID-19-Ausbrüchen in Deutschland. Epidemiologisches Bulletin, 38, 3-12. DOI: 10.25646/7093.

DRZEWOSZEWSKA, N., PIETRZAK, M. B., WILK, J. (2013). Grawitacyjny model przepływów handlowych między krajami Unii Europejskiej w dobie globalizacji. Roczniki Kolegium Analiz Ekonomicznych, 30, 187-202, [Online]. Available: http:// rocznikikae.sgh.waw.pl/p/roczniki kae z30 12.pdf [Accessed 29 December 2020].

EBOLI, L., MAZZULLA, G. (2012). Structural equation modelling for analysing passengers' perceptions about railway services. Procedia - Social and Behavioral Sciences, 54, 96-106. DOI: 10.1016/j.sbspro.2012.09.729.

FRIEDRICH, M. (1999). A multi-modal transport model for integrated planning. World Transport Research, Proceedings of the 8th World Conference on Transport Research, Vol. 2. Pergamon (Lehrstuhl für Verkehrsplanung und Verkehrsleittechnik, Institut für Straßen- und Verkehrswesen, Universität Stuttgart), [Online]. Available: https:// www.researchgate.net/publication/239329120 A MultiModal Transport Model for Integrated Planning [Accessed 20 September 2020].

GARBAROVA, M., STREZOVA, M. (2015). The trend analysis of transport development in Slovak Republic. Procedia Economics and Finance, 26, 584-591. DOI: 10.1016/ S2212-5671(15)00958-2.

HORNÁKK, M., PSENKA, T., KRIŽAN, F. (2013). The competitiveness of the longdistance public transport System in Slovakia. Moravian Geographical Reports, 21, 64-75. DOI: $10.2478 / \mathrm{mgr}-2013-0021$.

HØYER, K. G. (2004). From sustainable mobility to sustainable tourism. In Pineda, F. D., Brebbia, C. A., Mugiva, M., eds. Sustainable tourism. Ashurst, Southamptom (WIT Press), [Online]. Available: http://www.witpress.com/Secure/elibrary/papers/ST04/ ST04026FU.pdf [accessed 23 May 2021].

HUANG, D., LIU, Z., FU, X., BLYTHE, P. T. (2018). Multimodal transit network design in a hub-and-spoke network framework. Transportmetrica A: Transport Science, 14, 706-735. DOI: 10.1080/23249935.2018.1428234.

KOWALCZYK, K. (2019). Pasażerski transport kolejowy na obszarach aglomeracyjnych $w$ Polsce a rozwiazania multimodalne $w$ codziennych dojazdach do pracy. Lublin (Maria Curie-Skłodowska University).

LE-KLÄHN, D-T., HALL, C. M.,(2015). Tourist use of public transport at destinations - A review. Current Issues in Tourism, 18, 785-803. DOI: 10.1080/13683500.2014.948812.

LITMAN, T. (2008). Introduction to Multi-Modal Transportation Planning Principles and Practices. Victoria (Transport Policy Institute, „Efficiency, Equity, Clarity”), [Online]. Available: https://www.researchgate.net/publication/237820138 Introduction to MultiModal Transportation Planning [accessed 23 September 2020].

MAŁYSZ, M. (2019). Rola porannych połączeń kolejowych w kształtowaniu przestrzennej dostępności regionów. Urban and Regional Transport, 7, [Online]. Available: https:// www.researchgate.net/publication/335015588_Rola_porannych_polaczen_kolejowych W ksztaltowaniu przestrzennej dostepnosci_regionow [accessed 29 September 2020].

MĀEYSZ, M. (2020). Nocne pociągi dalekobieżne w przestrzeni Polski - zarys historyczny i perspektywy rozwoju. Geographical Studies, 160, 53-73, DOI: 10.4467/ 20833113PG.20.003.12261.

MASÁROVÁ, J., IVANOVÁ, E. (2016). Road infrastructure in the regions of the Slovak Republic and Poland. Bulletin of Geography. Socio-Economic Series, 33, 79-90. DOI: http://dx.doi.org/10.1515/bog-2016-0026.

MICHNIAK, D. (2011). The effects of European integration on the development of crossborder transport infrastructure: The example of Slovak-Polish boundary. Discussion Papers (Special), [Online]. Available: https://www.discussionpapers.rkk.hu/index.php/ DP/article/view/2470 [accessed 30 December 2020].

MRNÍKOVA, M., POLIAK, M., ŠIMURKOVÁ, P., HERNANDEZ, S., REUTER, N. (2017). How important is the integration of public passenger transport. LOGI Scientific Journal on Transport and Logistics, 8, 59-68. DOI: 10.1515/logi-2017-0017. 
RANCEW-SIKORA, D. (2007). Wakacje nad morzem, sprzedam. Kilka uwag o specyfice gospodarowania i konsumowania w kurorcie nadbałtyckim na przykładzie Władysławowa. In Mucha J., Nawojczyk M., Woroniecka G., eds. Kultura $i$ gospodarka. Ku antropologii życia gospodarczego we współczesnej Polsce. Katowice (Śląskie Wydawnictwa Naukowe), pp. 169-184, [Online]. Available: https:// www.researchgate.net/publication/313250200_Wakacje_nad_morzem_sprzedam _

Kilka uwag_o specyfice gospodarowania i konsumowania w kurorcie nadbaltyckim na przykladzie Wladyslawowa [accessed 30 December 2020].

ROSIK, P., KOWALCZYK, K. (2015). Development of road and railway infrastructure in Poland versus modal shift in the years 2000-2010. Geographical Studies, 248. Warsaw (Polish Academy of Sciences).

Van NES, R. (2002). Design of multimodal transport networks. A hierarchical approach, TRAIL-Thesis Series T2002/5, The Netherlands TRAIL Research School, [Online], Available: https://www.researchgate.net/publication/35732146 Design of multimodal transport networks a hierarchical approach [accessed 22 September 2020].

WIĘCKOWSKKI, M. (2002). Polish-Slovak transboundary cooperation. Geografický časopis, 54, 255-270.

WIECCKOWSKI, M. (2018). Cross-border transport accesibility on the Polish-Slovak borderland, Tarnowski Przeglad Nauk Społeczno-Humanistycznych, 2, 123-133.

WIĘCKOWSKI, M., MICHNIAK, D., BEDNAREK-SZCZEPAŃSKA, M., CHRENKA, B., IRA, V., KOMORNICKI, T., ROSIK, P., STĘPNIAK, M., SZEKELY, V., ŚLESZYNSKI, P., ŚWIĄTEK, D., WIŚNIEWSKI, R. (2012). Polish-Slovak borderland: transport accessibility and tourism. Warszawa-Bratysława (IGiPZ PAN; Geografický ústav Slovenskej akadémie vied).

YATSKIV, I., BUDILOVICH, E., GROMULE, V. (2017). Accessibility to Riga public transport services for transit passengers. Procedia Engineering, 187, 82-88. DOI: 10.1016/j.proeng.2017.04.353.

https://ec.europa.eu/transport/infrastructure/tentec/tentec-portal/map/maps.html

https://www.e-podroznik.pl

https://www.openrailwaymap.org

https://www.plk-sa.pl

Michat Matys $z$

\section{MULTIMODÁLNE RIEŠENIA AKO FAKTOR OVPLYVŇUJÚCI ZLEPŠENIE DOPRAVNEJ DOSTUPNOSTI - PRÍPADOVÁ ŠTÚDIA DOPRAVNÉHO SPOJENIA SLOVENSKA A BALTSKÉHO POBREŽIA POLSKA}

Multimodálna osobná doprava je dôležitou témou vedeckej diskusie na konci druhej dekády 21. storočia. Základom multimodálnej dopravy je doprava viacerými spôsobmi (módmi), pričom $\mathrm{k}$ prestupovaniu medzi jednotlivými spôsobmi dopravy dochádza v prestupných uzloch. Dôležité je to, že pri ceste $\mathrm{z}$ miesta $\mathrm{A}$ do miesta $\mathrm{B}$ prebieha väčšina času cesty vo vlaku, ktorý zabezpečuje dostupnost' v makromierke a umožňuje cestovanie medzi regiónmi, ktoré sú niekedy od seba dost' vzdialené. Následne cestujúci zmení spôsob dopravy na prestupnom uzle za regionálny autobus, ktorým príde až do cielového miesta. Vhodným príkladom použitia tohto modelu môžu byt' cesty zo Slovenska k Baltskému moru v Pol'sku. Pre Slovensko ako krajinu bez priameho prístupu k moru, ktorá susedí s Pol'skom, je nevyhnutné primerané spojenie s pobaltskými turistickými strediskami a prístavmi. Táto problematika je hlavnou témou príspevku.

V štúdii analyzujeme spojenia medzi Slovenskom a oblúbenými turistickými destináciami alebo kúpel'nými miestami pri Baltskom mori v Pol'sku prostredníctvom verejnej dopravy. Hodnotenie spojov z hl'adiska času trvania cesty, počtu prestupov a trasy je možné 
vd'aka použitiu ukazovatel'a možností dopravného prepojenia verejnou dopravou (PoPT) a jeho variantov, pričom sa zohl'adňujú aj d’alšie faktory, vrátane pomeru trasy ku najkratšej možnej trase a časov odchodu a príchodu. Analýza cestovného poriadku vlakov z rokov 2020 a 2021 ukázala, že najjednoduchším spôsobom, ako sa dostat' zo Slovenska na baltské pobrežie, je vycestovat' z Bratislavy do Břeclavi alebo zo Žiliny do Bohumína a prestúpit' na vlak Eurocity do Varšavy a Gdyne. Úroveň dopravnej dostupnosti baltského pobrežia nie je homogénna. Východná čast' pobrežia (napr. Gdansk, Sopot, Gdyňa alebo dokonca Władysławowo, Jastarnia a Hel) je l’ahšie dostupná (až na niektoré výnimky, napr. Łeba). Iné oblúbené strediská, ako Świnoujście and Międzyzdroje, sú menej dostupné, pretože cestovný poriadok neposkytuje adekvátne spojenia, čo sa prejavuje v diferenciácii PoPT hodnoty. Pre zlepšenie dostupnosti baltského pobrežia v Pol'sku zo Slovenska je nevyhnutné zabezpečit' adekvátne spojenia $\mathrm{v}$ prestupných uzloch. Vd'aka tomu je možné skrátit’ čas cestovania a znížit počet prestupovaní, čo sa odráža na zvýšení hodnoty ukazovatel'a PoPT. Navrhujeme preto urobit' niektoré dôležité zmeny, ktoré by len mierne zmenili cestovný poriadok, ale zjednodušili by cestovanie zo Slovenska k Balskému moru. Pre podporu cestovania verejnou dopravou, zvlášt' po kríze zapríčinenej pandémiou Covidu-19 v roku 2020 a 2021, by mal byt' pri zmenách cestovných poriadkov využitý v makromierke model multimodálnej osobnej dopravy. V tomto modeli je medzinárodný úsek cesty realizovaný vlakom (s odchodom skoro ráno alebo nočnými vlakmi, aby cestujúci ušetrili čas), pričom následné spojenia regionálnymi autobusmi v prestupných uzloch musia byt' zladené s cestovnými poriadkami vlakov. Tento vylepšený spôsob verejnej dopravy by mohol stimulovat' dopyt, ako aj ponuku s ciel'om naplnenia očakávaní cestujúcich. Lepšia mobilita by $\mathrm{v}$ konečnom dôsledku mohla priniest' pozitívne výsledky z hl'adiska atraktivity l'ahšie dostupných miest pre podnikanie alebo umiestnenie d’alších investícií.

Article first received: December 2020

Article accepted: May 2021 